\title{
The efficiency at industrial scale of a thermodynamic model for desulphurization of aluminium killed steels using slags in the system $\mathrm{CaO}-\mathrm{MgO}^{-\mathrm{Al}_{2}} \mathrm{O}_{3}-\mathrm{SiO}_{2}{ }^{(\cdot)}$
}

\author{
P.S. Nita*, I. Butnariu** and N. Constantin**
}

\begin{abstract}
In this paper are presented the results of some desulphurization trials in the ladle carried out at industrial scale for steels with low carbon, low alloyed and aluminum killed, using basic slag and argon bubbling. The main variables of treatment have been established on the basis of a thermodynamic model that includes parameters as sulphur capacity of the slag, optical basicity of oxides and of the slags, the activities of oxides in the slags and activities of elements in the liquid steel. Sulphur contents at the end of treatment, are close to the values predicted by the model. Low sulfur levels achieved in the process, facilitate the subsequent treatment with calcium to modify the inclusions. Finally an evaluation is presented concerning the effects resulting from the reoxidation of the melt on the main indicators, showing the efficiency of the applied treatment for desulphurization.
\end{abstract}

\section{La eficiencia a escala industrial de un modelo termodinámico para eliminar el azufre en los aceros calmados con aluminio utilizando escorias del sistema $\mathrm{CaO}-\mathrm{MgO}-\mathrm{Al}_{2} \mathrm{O}_{3}-\mathrm{SiO}_{2}$}

Resumen

Palabras clave

\begin{abstract}
En este trabajo se presentan los resultados de algunos ensayos de desulfuración en cuchara, llevados a cabo a escala industrial, para aceros con bajo contenido en carbono, de baja aleación y calmados con aluminio, utilizando escorias basicás y corriente de argón. Las principales variables del tratamiento se han establecido sobre la base de un modelo termodinámico que incluye parámetros como la capacitad de captación de azufre por las escorias, la basicidad óptica de los óxidos y de las escorias, las actividades de los óxidos en las escorias y las actividades de los elementos en el acero liquido. Los contenidos de azufre al final de tratamiento están cerca de los valores predichos por el modelo. Los bajos niveles de azufre alcanzados en el proceso, facilitan el posterior tratamiento con calcio para modificar las inclusiones. Se presenta, finalmente, una evaluación de los efectos derivados de la reoxidación del fundido sobre los principales indicadores que muestran la eficiencia del tratamiento de desulfuración aplicado.
\end{abstract}

Desulfuración; Escoria; Modelo termodinámico; Capacidad de captación de azufre; Reoxidación.

\section{DESULPHURIZATION OF LOW CARBON ALUMINIUM KILLED STEELS USING SLAGS AND ARGON BUBBLING}

For different purposes, a large category of low carbon, aluminium killed steels (LCAK) are used today. In this category different grades of High Strength Low Alloyed Steels (HSLA) are included. As a consequence of the important advances in the research and production of these grades, the field of application of this class of steel grades expanded continuously, because the rolled plates and sheets present a sum of favorable properties at high level. Medium and average thickness (HSLA) plates are among the rolled products whose properties have been improved in a severe manner applying adequate rolling technologies to corresponding continuous cast products of high quality, concerning the chemical composition, especially regarding very

\footnotetext{
(•) Trabajo reibido el día 17 de noviembre de 2008 y aceptado en su forma final el día 1 de junio de 2009.

* "Dunarea de Jos" University of Galati, Faculty of Metallurgy and Materials Science, Domneasca 47, Galati 800008, Romania. E-mail: pnita@ugal.ro

** Politehnica University, Splaiul Independentei 313, Bucuresti 60042, Romania.
} 
low and extra low contents of sulphur and high levels of purity in respect of non-metallic inclusions. The deleterious effects of the simultaneous actions due to sulphur and oxygen contents, exceeding low limits are due to the presence of them as deformable oxides and sulphides, whose action leads to decreasing of values of different mechanical properties. The influenced characteristics and properties of the final steel rolled products are anisotropy, ductility, resilience, formability properties, considered in the form of elongation, reduction of area, bendability, drawability, also other properties as cold forgeability, tougthness at low temperatures, fatigue strength ${ }^{[1]}$. To evaluate the deleterious effects of different types of inclusions, a systematized review, of the direct and indirect methods to evaluate the cleanliness of steels is given ${ }^{[2]}$. In hydrogen intergranular corrosion (HIC) resistant steels for sour gas tubes, sulphur content is very severe restricted at lower contents of $10 \mathrm{ppm}$ and phosphorus at contents below $50 \mathrm{ppm}^{[3 \text { and } 4]}$ and in steels for line pipes sulphur contents must be less than $30 \mathrm{ppm}^{[3]}$, the total oxygen content less than $30 \mathrm{ppm}{ }^{[5]}$ and also the maximal diameters of the inclusions are limited ${ }^{[6 \text { and } 7]}$. Besides the basic operations performed in oxygen converters, the treatments of steels in ladle, using adequate slags and argon bubbling are a common and a convenient way to obtain high quality liquid steels for continous casting, at low costs, using a simple equipments configuration and usual and available materials.

The technology of steel refining using slags is not at all a new one, but its successful and improved implementation is possible as consequences of the achievements in the characterization of the physicochemical properties of slags and in the characterization of the conditions of the thermodynamic equilibrium between slags and the metallic bath, applied in various industrial steel treatment reactors.

\section{THE THERMODYNAMIC PREDICTION MODEL}

In order to evaluate the efficiency of the treatments of steel under slags, the following indicators can be used:

1. sulphur content [S], in the steel during the desulphurization treatment, including the final content $\left[\begin{array}{ll}\% & S\end{array}\right]_{f}$ obtained in industrial conditions, compared with the predicted equilibrium value, $[\% \mathrm{~S}]_{\mathrm{e}}$ in initial and final conditions;

2. sulphur partition ratio between slag and steel, $\mathrm{L}_{\mathrm{S}}=($ mass \% S $) /[$ mass \% S], obtained after desulphurization treatment, compared with the equilibrium value predicted by the thermodynamic model, $\mathrm{L}_{\mathrm{S}, \mathrm{e}}$;

3. sulphur removal degree $\eta_{S}$, during desulphurization treatment, compared with the equilibrium predicted value $\eta_{\mathrm{S}, \mathrm{e}}$;

4. theoretical necessary proportion of the slag in the desulphurization process, in $\mathrm{kg} \mathrm{slag} / \mathrm{t}$ steel; this must be reported to a standard amount of the removed sulphur, expressed in the form of a number of units of concentration, in order to have a reference value for comparison of different procedures and technological variants, mainly having in view their efficiency;

5. kinetical aspects of the desulphurization process; only some restricted kinetic aspects will be presented in this paper.

These above mentioned indicators are the main dependent parameters of the prediction model of desulphurization, taken into consideration in the present paper.

The specific reaction describing the desulphurization process of a LCAK steel under $\mathrm{CaO}-\mathrm{MgO}-\mathrm{Al}_{2} \mathrm{O}_{3}-\mathrm{SiO}_{2}$ slags is the reaction No. 7 , in the table I. Using the system of reactions given in the table I and their associated thermodynamic data, compiled from many reference papers, the desulphurization indicators can be expressed in useful forms, mainly based on the quantity sulphur capacity of the slag $\mathrm{C}_{S}$, written at the equilibrium slagatmosphere:

$$
C_{S}=(\% S) \cdot\left[p_{\left\{O_{2}\right\}} / p_{\left\{S_{2}\right\}}\right]^{1 / 2}
$$

where, $(\% S)$ is the sulphur content in mass\% in slag, at equilibrium in the system slag-atmosphere; $p_{\left\{\mathrm{O}_{2}\right\}}$, $P_{\left\{S_{2}\right\}}$ partial pressure of oxygen and respective of sulphur in the atmosphere of the system, at equilibrium at the considered temperature.

For the quantity $\mathrm{C}_{\mathrm{S}}$, the following relation was established ${ }^{[8]}$, based on a selection consisting in a collection of experimental data containing 260 triplets $\left(\mathrm{C}_{S}, \mathrm{~T}, \Lambda\right)$ and a treatment combining the mathematical statistics and integral calculus:

$$
C_{S}=19.14-22.245 \Lambda+(61855 \Lambda-55785) / T
$$

where, $T$ is the absolute temperature, in $\mathrm{K}$; $\Lambda$ is the optical basicity of slag, computed for the slags in the system $\mathrm{CaO}-\mathrm{MgO}-\mathrm{Al}_{2} \mathrm{O}_{3}-\mathrm{SiO}_{2}$, based on the optical basicity of every oxide and on the electrically equivalent ionic fractions of each cation in slag and further, on the chemical composition of the slag. The resulted computation relation is the following: 
THE EFFICIENCY AT INDUSTRIAL SCALE OF A THERMODYNAMIC MODEL FOR DESULPHURIZATION OF ALUMINIUM KILLED STEELS USING SLAGS IN THE SYSTEM CAO-MGO-AL $\mathrm{O}_{3}-\mathrm{SIO}_{2}$ LA EFICIENCIA A ESCALA INDUSTRIAL DE UN MODELO TERMODINÁMICO PARA ELIMINAR EL AZUFRE EN LOS ACEROS CALMADOS CON ALUMINIO UTILIZANDO ESCORIAS DEL SISTEMA CAO-MGO-AL $\mathrm{O}_{3}$-SIO ${ }_{2}$

Table I. Reactions and thermodynamical data involved in the desulphurization process using slags ${ }^{[8]}$

Tabla I. Reacciones y datos termodinámicos implicados en el proceso de desulfuración con escorias ${ }^{[8]}$

\begin{tabular}{|c|c|c|}
\hline No. & Reaction & $\Delta \mathbf{G},[\mathbf{J}]$ \\
\hline 1 & $1 / 2\left\{\mathrm{O}_{2}\right\} \Leftrightarrow[\mathrm{O}]_{1 \%}$ & $\Delta \mathrm{G}_{1}^{0}=-114361-5.57 \mathrm{~T}$ \\
\hline 2 & $1 / 2\left\{S_{2}\right\} \Leftrightarrow[S]_{1 \%}^{1 \%}$ & $\Delta G_{2}^{0}=-131880+22.05 T$ \\
\hline 3 & $<\mathrm{CaS}>+1 /{ }_{2}\left\{\mathrm{O}_{2}\right\} \Leftrightarrow<\mathrm{CaO}>+1 /{ }_{2}\left\{\mathrm{~S}_{2}\right\}$ & $\Delta \mathrm{G}_{3}{ }^{0}=-92000+2.55 \mathrm{~T}$ \\
\hline 4 & $\left.2[\mathrm{Al}]+3[\mathrm{O}] \Leftrightarrow<\mathrm{Al}_{2} \mathrm{O}_{3}\right\rangle$ & $\Delta \mathrm{G}_{4}^{0}=-1287760+429.25 \mathrm{~T}$ \\
\hline 5 & {$[\mathrm{~S}]+1 / 2\left\{\mathrm{O}_{2}\right\} \Leftrightarrow[\mathrm{O}]+1 / 2\left\{\mathrm{~S}_{2}\right\}$} & $\Delta \mathrm{G}_{5}^{0}=\Delta \mathrm{G}_{1}{ }^{0}-\Delta \mathrm{G}_{2}{ }^{0}=17519-27.62 \mathrm{~T}$ \\
\hline 6 & $<\mathrm{CaS}>+[\mathrm{O}] \Leftrightarrow<\mathrm{CaO}>+[\mathrm{S}]$ & $\Delta G_{6}^{0}=-\Delta G_{1}{ }^{0}+\Delta G_{2}{ }^{0}+\Delta G_{3}{ }^{0}=-109519+30.17 T$ \\
\hline 7 & $<\mathrm{CaO}>+2 / 3[\mathrm{Al}]+[\mathrm{S}] \Leftrightarrow<\mathrm{CaS}>+1 / 3<\mathrm{Al}_{2} \mathrm{O}$ & $\Delta \mathrm{G}_{7}^{0}=1 / 3 \Delta \mathrm{G}_{4}^{0}-\Delta \mathrm{G}_{6}^{0}=-319734+112.91 \mathrm{~T}$ \\
\hline
\end{tabular}

\section{$\Lambda=(1.783 C+1.925 M+1.756 \mathrm{~A}+1.598 S) /(1.783 \mathrm{C}+2.48 \mathrm{M}+2.943 \mathrm{~A}+3.335)(3)$}

where, $\mathrm{C}=$ mass $\% \mathrm{CaO} ; \mathrm{M}=$ mass $\% \mathrm{MgO} ; \mathrm{A}=$ mass $\% \mathrm{Al}_{2} \mathrm{O}_{3} ; \mathrm{S}=$ mass $\% \mathrm{SiO}_{2}$.

The main steps in the establishing of the main parameters of the steel desulphurization model and of the main indicators, to evaluate the efficiency of the treatment under slag, are presented bellow.

\subsection{Sulphur content in steel}

From the equilibrium constant of the reaction No. 7, in table I, it results the following relation for the sulphur activity in steel $\mathrm{a}_{[\mathrm{S}]}$, in equilibrium conditions, taking into consideration the slag saturation with sulphur $\left(\mathrm{a}_{<\mathrm{CaS}\rangle}=1\right)$ :

$$
\lg a_{[S]}=1 / 3 \lg a_{\left\langle A I_{2} \mathrm{O}_{3}\right\rangle}-\lg a_{\langle\mathrm{CaO}\rangle}-2 / 3 \lg a_{[A I]}-\lg k_{7}
$$

The activities of $\mathrm{CaO}\left(a_{\langle\mathrm{CaO}\rangle}\right)$ and $\mathrm{Al}_{2} \mathrm{O}_{3}\left(a_{\left\langle\mathrm{Al}_{2} \mathrm{O}_{3}\right.}\right)$ in slags are according to Raoult law with the reference state the pure solid for each considered oxide. For each element in liquid steel activity is computed based on the infinite dilute solution as standard state normalized at $1 \mathrm{mass} \%$. For them statistical regression relations were established for the ranges of compositions of slag interesting in desulphurization process, valid for slags in the system $\mathrm{CaO}-\mathrm{Al}_{2} \mathrm{O}_{3}-\mathrm{SiO}_{2}$, starting from data ${ }^{[9]}$ :

$$
\begin{gathered}
\operatorname{lga}_{(\mathrm{CaO})}=-1.661+0.042\left(\% \mathrm{Al}_{2} \mathrm{O}_{3}\right)-0.051\left(\% \mathrm{SiO}_{2}\right) \\
\lg _{\left\langle\mathrm{Al}_{2} \mathrm{O}_{3}\right\rangle}=-4.7878+0.07424\left(\% \mathrm{Al}_{2} \mathrm{O}_{3}\right)+0.05529\left(\% \mathrm{SiO}_{2}\right)
\end{gathered}
$$

In liquid LCAK steel, considered as a dilute solution, the activity of aluminium normalized at $1 \%$ is $\mathrm{a}_{[\mathrm{Al}]}=1$. This is taken into account in the relation (4) and in the other derived relations. The relations (5) and (6) are simplified mathematical expressions of those obtained from the equilibrium constant of the corresponding reaction. They have been obtained by a linearizing operation, for practical reasons in order to facilitate an easy handling in mathematical expressions where they are included. Based on the relation (5), the resulting relation for the major indicator of the desulphurization process under slags is the following:

$$
\lg a_{[S]}=-6.3157+0.0667\left(\% \mathrm{Al}_{2} \mathrm{O}_{3}\right)+0.0694\left(\% \mathrm{SiO}_{2}\right)-2 / 3 \lg \mathrm{a}_{[\mathrm{AI}]}
$$

Considering for sulphur in steel the activity $\mathrm{a}_{[\mathrm{S}]}$, taking an activity coefficient of sulphur in the low carbon, low alloyed steels $\mathrm{f}_{[S]} \approx 1$, it results the corresponding content of sulphur in slag [S]. In the slags based on systems $\mathrm{CaO}-\mathrm{Al}_{2} \mathrm{O}_{3}-\mathrm{SiO}_{2}$ and $\mathrm{CaO}-\mathrm{MgO}-\mathrm{Al}_{2} \mathrm{O}_{3}-\mathrm{SiO}_{2}$, at maximal contents of $\mathrm{MgO}$ and $\mathrm{SiO}_{2}$ bellow $10 \%$ each, the nomogram from figure 1 , obtained on the base of the relations (2)-(10) gives a fast and general view on the independent and dependent parameters involved in desulphurization of LCAK and low alloyed steels, including HSLA steels grades. The major advantage of this nomogram is that it can be read according to needs, whatever is the sense of running. At low contents of $\mathrm{MgO}$ in the slags $(\mathrm{MgO}<8-10$ mass \%) belonging to the system $\mathrm{CaO}-\mathrm{MgO}-\mathrm{Al}_{2} \mathrm{O}_{3}-\mathrm{SiO}_{2}$ the content of $\mathrm{MgO}$ can be added to that of $\mathrm{CaO}$ in the computations of activities of $\mathrm{CaO}$ in slag ( Rel. (5)). This simplification is suggested because there is an acceptable equivalence between the two oxides expressed in the form $\Lambda_{\mathrm{MgO}} / \mathrm{M}_{\mathrm{MgO}} \approx \Lambda_{\mathrm{CaO}} / \mathrm{M}_{\mathrm{CaO}} \cdot \mathrm{M}_{\mathrm{MgO}}$ and $\mathrm{M}_{\mathrm{CaO}}$ are the molar mass of these oxides and $\Lambda_{\mathrm{MgO}}$ and $\Lambda_{\mathrm{CaO}}$ are the 


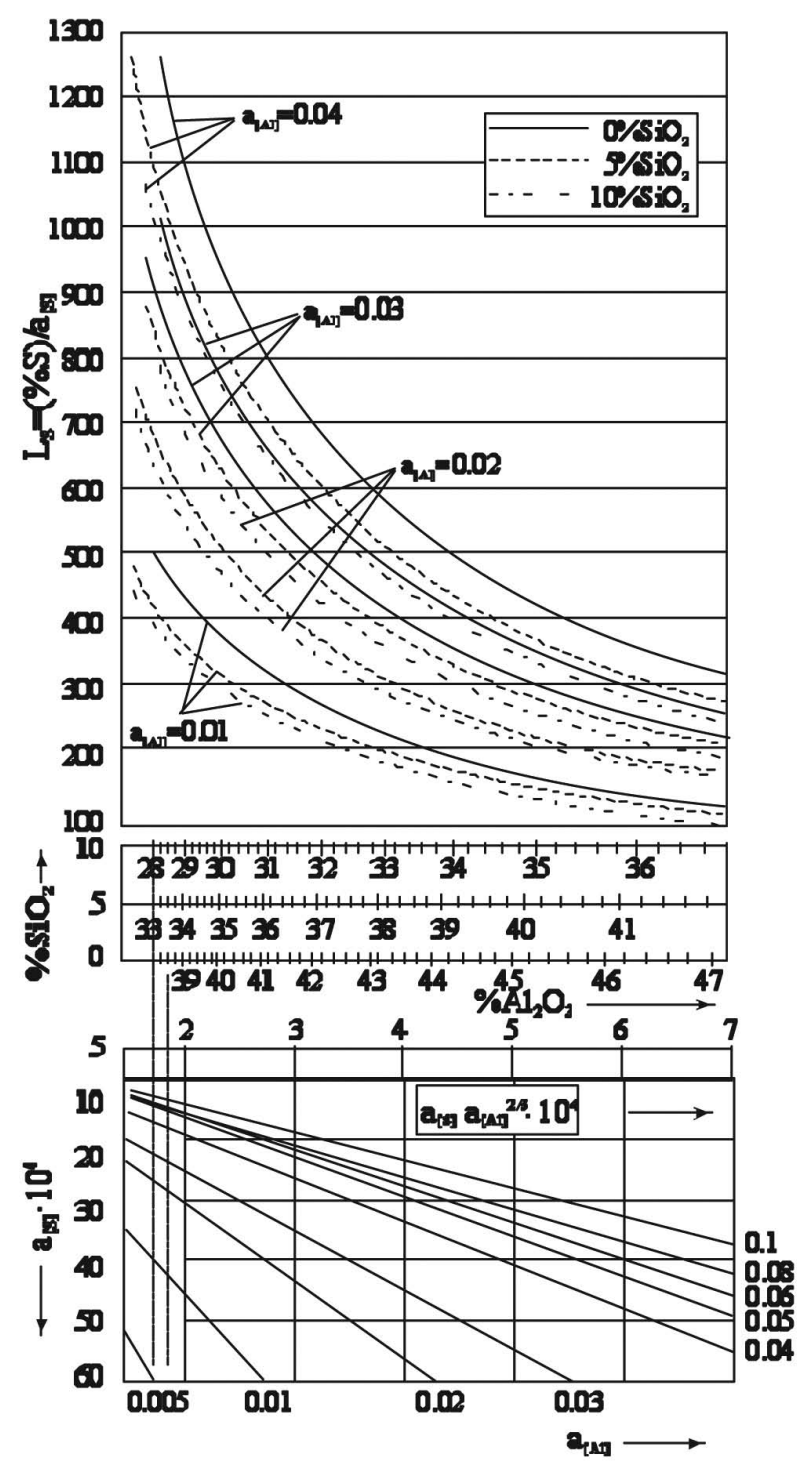

Figure 1 Evaluation and interpretation of the operation parameters in steel desulphurization under $\mathrm{CaO}-\mathrm{Al}_{2} \mathrm{O}_{3}-\mathrm{SiO}_{2}$ slags.

Figura 1. Evaluación e interpretación de los parámetros de operación que intervienen en la desulfuracion del acero con escorias $\mathrm{CaO}-\mathrm{Al}_{2} \mathrm{O}_{3}-$ $\mathrm{SiO}_{2}$.

corresponding values of the optical basicity for the considered oxides.

\subsection{Sulphur partition ratio between slag and steel}

In equilibrium conditions it results the following relation for the sulphur partition ratio between slag and steel $\mathrm{L}_{\mathrm{S}}$ :

$$
\lg L_{S}=\lg C_{S}+\lg k_{5}-\lg a_{[0]}
$$

The activity of oxygen $\mathrm{a}_{[\mathrm{O}]}$ in liquid steel results from the reaction No. 4 in the table I:

$$
\lg a_{[O]}=1 / 3 a_{\left(\mathrm{Al}_{2} \mathrm{O}_{3}\right\rangle}-2 / 3 \lg _{[\mathrm{AA}]}-1 / 3 \lg k_{4}
$$

$k_{4}$ in relation (8) and $k_{5}$ in relation (9) represents equilibrium constant of the reaction No. 4 and respective of the reaction No. 5, from table I. Introducing temperature $\mathrm{T}=1,873.15 \mathrm{~K}$ in the relation (2) the following relation is obtained:

$$
\lg C_{S}=10.7669 \Lambda-10.64
$$

Introducing the value of alumina activity in slag $\mathrm{a}_{\left\langle\mathrm{Al}_{2} \mathrm{O}_{3}>\right.}$ given in the relation (6) and following all steps, the relation used in computation, at the temperature $1,873 \mathrm{~K}$ i.e. the sulphur partition ratio between slag and steel $\mathrm{L}_{\mathrm{S}}$ results in the following form:

$$
\left.\lg L_{S}=10.7669 \Lambda-3.552+2 / 3 / \lg a_{[N \mid}\right]-0.02474\left(\% A_{2} O_{3}\right)-0.01843\left(\% S_{S} O_{2}\right)
$$

\subsection{Sulphur removal degree}

Sulphur removal degree $\eta_{\mathrm{S}}$, during desulphurization treatment, is a very efficient tool to characterize the efficiency of the treatment with slag, but always this must be compared with the equilibrium predicted value $\eta_{\mathrm{S}, \mathrm{e}}$, at different moments of treatment or at the final moment:

$$
\eta_{S, e}=\frac{[\% S]_{i}-[\% S]_{t}}{[\% S]_{i}} \cdot 100, \%
$$

where, $[\% \mathrm{~S}]_{\mathrm{i}}$ - the initial content of sulphur in steel before treatment with slag; $[\% \mathrm{~S}]_{\mathrm{t}}-$ the sulphur content in steel at the moment $t$ of treatment; this could be taken either the value chemically determined at the moment $t$, or the equilibrium value of sulphur, resulted at the moment $t$, considering the soluble aluminium content and the associated value of the oxygen activity in steel, from the equilibrium constant of the reactions No. 4 and No. 7. A value of the oxygen activity in steel, obtained measuring the activity of oxygen, is also useful. 
THE EFFICIENCY AT INDUSTRIAL SCALE OF A THERMODYNAMIC MODEL FOR DESULPHURIZATION OF ALUMINIUM KILLED STEELS USING SLAGS IN THE SYSTEM CAO-MGO-AL $2 \mathrm{O}_{3}$-SIO LA EFICIENCIA A ESCALA INDUSTRIAL DE UN MODELO TERMODINÁMICO PARA ELIMINAR EL AZUFRE EN LOS ACEROS CALMADOS CON ALUMINIO UTILIZANDO ESCORIAS DEL SISTEMA CAO-MGO-AL $\mathrm{O}_{3}$-SIO ${ }_{2}$

\subsection{Necessary amount of slag}

The theoretical amount of necessary slag for desulphurization of the steel, between the initial content $[\% \mathrm{~S}]_{\mathrm{i}}$ up down to the equilibrium level content $[\% \mathrm{~S}]_{\mathrm{e}}$ is given by following relation:

$$
p_{\text {slag }}=\frac{\left([\% S]_{i}-[\% S]_{e}\right) \cdot 10^{3}}{L_{S, e} \cdot[\% S]_{i}-(\% S)_{i}}, \text { Kg slag/t steel }
$$

The initial content of sulphur in the desulphurization slag $(\% \mathrm{~S})_{\mathrm{i}}$ is very low and frequently could be neglected. From the relation (13) it is obvious that the decrease of the equilibrium values of the sulphur partition ratio $\mathrm{L}_{\mathrm{S}, \mathrm{e}}$, caused by the modification of the equilibrium conditions will lead to the increasing of the necessary slag proportion $\mathrm{p}_{\text {slag }}$. As it results from the present analysis, the decrease of aluminium activity in steel, due to the reoxidization and the decrease of the sulphide capacity of slag $\mathrm{C}_{\mathrm{S}}$, due to the detrimental changes of the chemical composition of slag, will lead to the increase of the necessary slag proportion.

\section{EXPERIMENTAL TRIALS AND RESULTS}

An extended experimental program at plant scale was applied consisting in treatments of heats of average mass of $180 \mathrm{t}$, processed in LD converters at Galati Complex Steel - Romania, actually member of ArcelorMittal. The final composition of the liquid steel was in the range $\mathrm{C}=0.06-0.08 \% ; \mathrm{Mn}=1.54-1.65 \%$; $\mathrm{Si}=0.025-0.44 \% ; \mathrm{P}=0.010-0.024 \% ; \mathrm{S}=0.0020$. $0.0040 \% ; \mathrm{Al}_{\text {tot }}=0.010-0.09 \% ; \mathrm{Nb}=0.032-0.046 \%$; $\mathrm{V}=0.040-0.072 \%$. The main purposes of the applied treatments have been to obtain low contents of sulphur and total oxygen ( $<30 \mathrm{ppm}$ each) and a high purity in non-metallic inclusions. From them, a set of 5 experimental heats are presented because they are representative for all practical encountered situations. The treatment slags for desulphurization have been obtained based on refractory materials, admixtures and lime of common quality in a LD converters steelmaking plant.

The adequate chemical compositions of desulphurizing slags are presented in the table II .They have been obtained using an adequate computation

Table II. Composition of the desulphurizing slags used in experimental trials

Tabla II. Composición de las escorias desulfurantes utilizadas en los procesos experimentales

\begin{tabular}{|c|c|c|c|c|c|c|c|c|c|c|}
\hline \multirow[b]{2}{*}{ Heat } & \multicolumn{9}{|c|}{ Chemical composition . mass \% } & \multirow[b]{2}{*}{$\begin{array}{c}\text { Optical } \\
\text { basicity } \\
\Lambda\end{array}$} \\
\hline & C & $\mathrm{Fe}$ & Mn & $\mathrm{CaO}$ & MgO & $\mathrm{SiO}_{2}$ & $\mathrm{Al}_{2} \mathrm{O}_{3}$ & $\mathbf{S}$ & $\begin{array}{l}\text { Others. } \\
(\text { mainly } \\
\left.\mathrm{CaF}_{2}\right)\end{array}$ & \\
\hline 1 & 0.19 & 0.35 & 0.10 & 44.93 & 8.02 & 6.59 & 29.60 & 0.37 & 9.85 & \\
\hline * & - & - & - & 50.20 & 8.96 & 7.36 & 33.06 & 0.41 & 11.5 & 0.7571 \\
\hline 2 & 0.17 & 9.72 & 0.60 & 44.64 & 6.75 & 10.55 & 22.20 & 0.34 & 6.09 & \\
\hline * & - & - & - & 52.84 & 8.00 & 12.48 & 26.28 & 0.40 & 8.0 & 0.7552 \\
\hline 2 & 0.19 & 8.92 & 0.34 & 47.57 & 5.70 & 7.55 & 25.90 & $0.81^{* *}$ & 3.02 & \\
\hline * & - & - & - & 54.34 & 6.51 & 8.63 & 29.59 & $0.93^{* *}$ & 3.45 & 0.7662 \\
\hline 3 & 0.17 & 0.70 & 0.21 & 46.99 & 9.50 & 5.16 & 34.04 & 0.54 & 2.69 & \\
\hline * & - & - & - & 48.83 & 9.87 & 5.36 & 35.37 & 0.56 & 2.8 & 0.7581 \\
\hline 3 & 0.19 & 42.68 & 1.17 & 25.84 & 5.49 & 3.72 & 18.50 & 0.34 & 2.07 & \\
\hline * & - & - & - & 47.95 & 10.18 & 6.90 & 34.32 & 0.63 & 3.8 & 0.7526 \\
\hline 4 & 0.21 & 0.70 & 0.010 & 51.69 & 6.33 & 2.04 & 32.56 & $0.88^{* *}$ & 5.49 & \\
\hline * & - & - & - & 55.28 & 6.77 & 2.18 & 34.82 & $0.94^{* *}$ & 5.87 & 0.7837 \\
\hline 4 & 0.10 & 0.46 & 0.10 & 51.98 & 6.96 & 2.07 & 34.04 & $0.91^{* *}$ & 3.38 & \\
\hline * & - & - & - & 54.17 & 7.25 & 2.15 & 35.47 & $0.94^{* *}$ & 3.59 & 0.7805 \\
\hline
\end{tabular}

${ }^{*}$ Recomputed chemical composition considering slag only in the system $\mathrm{CaO}-\mathrm{MgO}-\mathrm{Al}_{2} \mathrm{O}_{3}-\mathrm{SiO}_{2}$;

${ }^{* *}$ contents of sulphur in the final slags; the others are values at moments around half of the treatment duration;

*** obtained mainly by difference from $100 \%$. 
algorithm, based on the equations of the thermodynamic model presented before and on mass balance equations, written for the important components of slags, mainly those from relation (3). Some preliminary evaluated premises, necessary in the mass balance of the model, were also taken into account, among them being the consumption of refractory lining of the ladle and the amount of slag transferred from converter in the treatment ladle, both at a known chemical compositions. The equations of the model have allowed the obtaining of slag compositions included in the regions of the particular systems $\mathrm{CaO}-5 \% \mathrm{MgO}-\mathrm{Al}_{2} \mathrm{O}_{3}-\mathrm{SiO}_{2}$ and $\mathrm{CaO}-10 \% \mathrm{MgO}-\mathrm{Al}_{2} \mathrm{O}_{3}-\mathrm{SiO}_{2}$ where high values of the equilibrium sulphur partition ratio $\mathrm{L}_{\mathrm{S}, \mathrm{e}}$ can be obtained. Many of these compositions are at the limits of the liquid field, towards the solid domain at the temperature $1873 \mathrm{~K}$ and present a relative narrow liquid field. Therefore, to ensure the slag in permanent and fully liquid state, an amount of fluorine was added in order to bring effectively about $3-4 \%$ mass $\mathrm{CaF}_{2}$ in the compositions of slags.In order to obtain this, the effective adding was increased with about an equivalent of $2-3 \% \mathrm{CaF}_{2}$, representing the lose of $\mathrm{CaF}_{2}$ by different possible and known mechanisms.It is appreciated that this enlarge the liquid domain in slag, which has a lower melting temperature with at least $50 \mathrm{~K}$.In the same time it is appreciated, according to many researchers, that the values for the sulphur capacity of the slags are not increased, but the mass transfer rate is improved due to the higher fluidity of the slags containing $\mathrm{CaF}_{2}$. The amounts for mixture according to the established receipt have been dried and preheated before to be introduced and this operation was performed according to a certain procedure.

The practice of steel treatments with slags has shown that at least about one third of slag amount in ladle is practically inactive because it is cold and viscous. This region is situated mainly towards the refractory lining of the ladle and at the surface of the slag, enough far from the eye of argon bubbling. Under these remarks, the total amount of slag used in treatment, resulting from all sources can be computed using the mass balance and the different imposed conditions. One of them could be that to obtain a final content of sulphur in slag lower than the solubility of sulphur in slag; for safety this value is usually selected lower than 1 mass \%. Other restrictions could be used in establishing the maximal value of the final amount of treatment slag. For example it could be imposed the condition to have a certain limited content of $\mathrm{SiO}_{2}$, usually lower than 5-8 \%, or to have a certain height of the slag layer in the ladle.

The practical amount of slag of treatment was established to be higher with about 20-30\% (heats $1,3,4$, Table III) and the values obtained after desulphurization treatment are in good agreement with the prediction of the present thermodynamic model. The increasing with about $70 \%$ of the slag (heat 2, Table III) over the theoretical established amount, due to the necessity to have a certain imposed height of the covering layer of slag, did not contributed to obtain a lower final sulphur content. This proves that according to the relation (4), in the conditions of known temperature and chemical composition of the slag and of the liquid steel, the activity of aluminium in the liquid steel and consequently, the activity of oxygen in the liquid steel plays the essential role in determination of the lowest possible sulphur content which could be obtained in the established conditions. The evolution of the sulphur content in the liquid steel from the moment of starting of the tapping, up to the final presumed point of treatment is presented in the figure 2 . It results that during about 12-20 min of treatment in ladle by argon bubbling, after the end of tapping, a value of the sulphur content close to the thermodynamic predicted value, is

Table III. Sulphur content in the ladle at the end of the treatment under slags at $1873 \mathrm{~K}$. obtained using the present model

Tabla III. Contenido de azufre en la cuchara al final del tratamiento con escorias (1873K). obtenido mediante la utilización del modelo presente

\begin{tabular}{cccccc}
\hline Heat & $\mathbf{a}_{\text {[A] }}$ & $\begin{array}{c}\mathbf{L}_{\text {S.e }} \\
\text { relation (7) }\end{array}$ & $\begin{array}{c}\text { Slag proportion } \\
\text { Kg/t steel } \\
\text { determined/computed }\end{array}$ & $\begin{array}{c}\text { Predicted } \\
{[\% \text { S }]_{\mathbf{e}}} \\
(\text { Rel. 8) }\end{array}$ & $\begin{array}{c}\text { Experim. } \\
\text { Final value } \\
{[\% \text { S }]_{\mathbf{f}}}\end{array}$ \\
\hline 1 & 0.027 & 400 & $14.2 / 12.8$ & 0.0024 & 0.0025 \\
2 & 0.020 & 440 & $12.5 / 7.13$ & 0.0029 & 0.0032 \\
3 & 0.039 & 440 & $14.2 / 12.19$ & 0.0022 & 0.0026 \\
4 & 0.090 & 1725 & $14.2 / 11.08$ & 0.0006 & $0.0020^{(*)}$ \\
\hline
\end{tabular}

${ }^{(*)}$ some results of the analysis indicated $0.0014 \% \mathrm{~S}$. 
THE EFFICIENCY AT INDUSTRIAL SCALE OF A THERMODYNAMIC MODEL FOR DESULPHURIZATION OF ALUMINIUM KILLED STEELS USING SLAGS IN THE SYSTEM CAO-MGO-AL $\mathrm{O}_{3}$-SIO, LA EFICIENCIA A ESCALA INDUSTRIAL DE UN MODELO TERMODINÁMICO PARA ELIMINAR EL AZUFRE EN LOS ACEROS CALMADOS CON ALUMINIO UTILIZANDO ESCORIAS DEL SISTEMA CAO-MGO-AL_O ${ }_{3}$-SIO 2

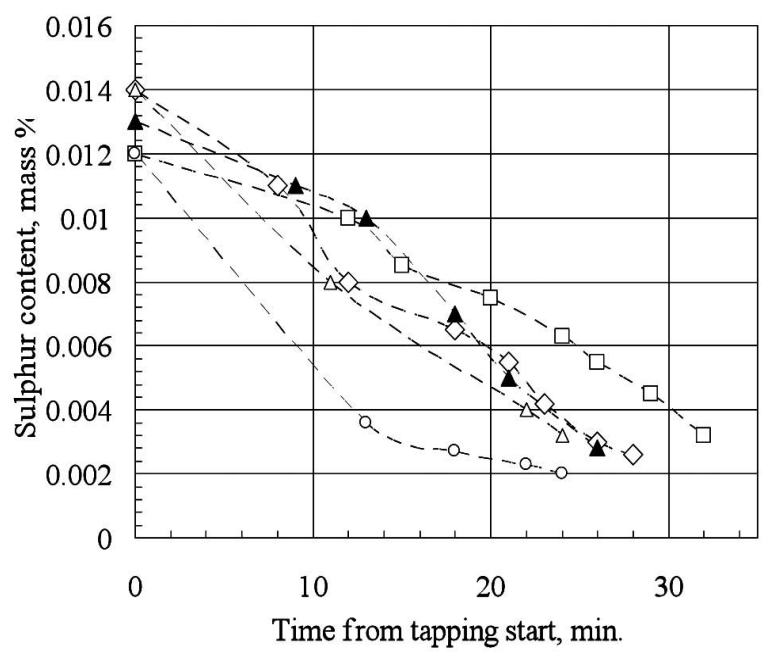

Figure 2. Evolution of sulphur content during desulphurization treatments under slag for the experimental heats; $\diamond$-heat 1 ; $\square$-heat $2 ; \boldsymbol{\Delta}$-heat 3; o-heat 4; $\triangle$-heat 5.

Figura 2. Evolución de contenido de azufre durante tratamientos de desulfuración con escorias del sistema $\mathrm{CaO}-\mathrm{MgO}-\mathrm{Al}_{2} \mathrm{O}_{3}-\mathrm{SiO}_{2}$ para los ensayos experimentales; $\diamond$-ensayo 1 ; $\square$-ensayo 2; $\Delta$-ensayo 3; o- ensayo 4; $\triangle$-ensayo 5.

obtained (Table III). Based on the above results, a trial was performed, consisting in treatment of a heat, of a close chemical composition, using an averaged receipt, to obtain the desulphurization slag (heat 5, Fig. 2), without to perform all the computational steps involving the model. The results are very good and confirm the procedure using the present model. Weighting the final amount of slag in the ladle, based on the final chemical composition of the steel and of the slag, the presumed conditions of computations have been confirmed and the final content of sulphur and the desulphurization degree of the steel have been found to be close to those predicted thermodynamically. Usually, final contents of sulphur and of the total oxygen in steel, lower than 30ppm, have been obtained making possible an efficient final treatment of the steels with CaSi cored wire at a low and controlled consumption. Neglecting the value of sulphur in converter before tapping, for the rest of points in the figure 2, statistical dependencies of the sulphur contents upon the time of treatment have been established, up to the time moment of the establishing the equilibrium in the experimental conditions. They are presented in the table IV as polynomial relations of the highest value of determination coefficient $\mathrm{D}=R_{x, y}^{2}$. The time dependency of the sulphur content evolution is obvious and strong in a close manner for all analyzed heats. The dependencies for heats 1, 2, 3 presented in the graphic form (Fig. 2) show a particular behaviour at a sulphur content around $0.006 \%$, first consisting in a slowing of the sulphur content decrease, followed by a faster decrease, or in a modification of the slope of the curve, but without to be a pure inflexion point, according to the mathematical analysis. This behaviour could be attributed to an exchange of the adsorption of the sulphur on the interface, which presents a modification at this content of sulphur in iron, according to the literature ${ }^{[10]}$.

\section{INFLUENCES OF THE CHEMICAL COMPOSITION MODIFICATIONS OF SLAG DURING DESULPHURIZATION}

The quality requirements for HSLA steels can be affected by some possible undesired contributions of the treatment with slag, during desulphurization process. Due to the reduction of some less stabile

Table IV. Evolution of the sulphur content in steel upon the time during treatment under slag

Tabla IV. Evolución con el tiempo del contenido del azufre en el acero durante el tratamiento con escoria

\begin{tabular}{cll}
\hline Heat & \multicolumn{1}{c}{ Statistical relation $[\% \mathbf{S}]=\mathbf{f}(\mathbf{t})$} & $\left.{ }^{*}\right) \mathbf{D}=\mathbf{R}^{\mathbf{2}} \mathbf{s , t}$ \\
\hline 1 & $4 \cdot 10^{-7} \mathrm{t}^{4}-3 \cdot 10^{-5} \mathrm{t}^{3}+7 \cdot 10^{-4} \mathrm{t}^{2}-8.3 \cdot 10^{-3} \mathrm{t}+4.44 \cdot 10^{-2}$ & 0.9993 \\
2 & $10^{-7} \mathrm{t}^{4}-10^{-5} \mathrm{t}^{3}+4 \cdot 10^{-4} \mathrm{t}^{2}-5.7 ? 10^{-3} \mathrm{t}+4.08 \cdot 10^{-2}$ & 0.9986 \\
3 & $2 \cdot 10^{-5} \mathrm{t}^{2}-10^{-3} \mathrm{t}+1.7 \cdot 10^{-2}$ & 1.0 \\
4 & $-2 \cdot 10^{-6} \mathrm{t}^{3}+9 \cdot 10^{-5} \mathrm{t}^{2}-1.9 \cdot 10^{-3} \mathrm{t}+1.61 \cdot 10^{-2}$ & 1.0 \\
5 & $2 \cdot 10^{-8} \mathrm{t}^{4}+2 \cdot 10^{-6} \mathrm{t}^{3}-10^{-4} \mathrm{t}^{2}+1.7 \cdot 10^{-3} \mathrm{t}+0.41 \cdot 10^{-2}$ & 1.0 \\
\hline
\end{tabular}

${ }^{(\star)}$ Coefficient of determination $\mathrm{D} ; \mathrm{R}_{\mathrm{S}, \mathrm{t}}$-coefficient of statistical corelation between the sulphur content in steel $[\% \mathrm{~S}]$ and time $\mathrm{t}$. 
oxides in slag and because of the reoxidization of the steel by desulphurization, according to the exchange reaction between sulphur and oxygen at interface steel-slag, included in the reaction No. 7 in the table I, the final sulphur contents in steel are higher than the values expected to be obtained, taking into account the conditions in the initial stage. Using slags $\mathrm{CaO}-\mathrm{Al}_{2} \mathrm{O}_{3}-\mathrm{MgO}-\mathrm{SiO}_{2}$, in the composition domain of practical interest in industrial scale technologies, for $\mathrm{SiO}_{2}<6-8 \%$, at $\mathrm{Al}_{\text {sol }}<0.04 \%$ there is not a perceptible reoxidization of steel by reduction of silica from slag with aluminium. Several effects of the small changes of the chemical composition of slag, caused by the secondary reoxidization are discussed, showing possible measures of correction. Simultaneous with the desulphurization, an amount of $\mathrm{Al}_{2} \mathrm{O}_{3}\left(q_{\mathrm{Al}_{2} \mathrm{O}_{3}}\right)$ results, due to oxidization of the corresponding amount of consumed aluminium $\left(q_{\mathrm{Al} . \text { cons }}\right)$ and an amount of $\mathrm{CaO}\left(1_{\mathrm{CaO}}\right)$ is consumed by the amount of sulphur transferred into $\operatorname{slag}(\Delta[S])$, where it gives $\mathrm{CaS}$. These amounts are given in forms according to the stoichiometry, based on the quantity $\Delta[\mathrm{S}]$ which is taken into consideration:

$$
\begin{gathered}
q_{A l_{2} O_{3}}=\Delta[\mathrm{S}] \frac{M_{A l_{2} O_{3}}}{3 M_{S}}=1.06 \Delta[\mathrm{S}] \mathrm{Kg} / 100 \mathrm{~kg} \text { steel } \\
q_{C a O}=\Delta[\mathrm{S}] \frac{M_{C a O}}{M_{S}}=1.77 \Delta[\mathrm{S}] \mathrm{Kg} / 100 \mathrm{~kg} \text { steel } \\
q_{C a O}=\Delta[\mathrm{S}] \frac{M_{C a O}}{M_{S}}=1.77 \Delta[\mathrm{S}] \mathrm{Kg} / 100 \mathrm{~kg} \text { steel } \\
q_{A l . c o n s}=\Delta[\mathrm{S}] \frac{2 M_{A l}}{3 M_{S}}=0.56 \Delta[\mathrm{S}] \mathrm{Kg} / 100 \mathrm{~kg} \text { steel }
\end{gathered}
$$

where, $\Delta[\mathrm{S}]$ is the amount of sulphur removed from steel into the slag by the desulphurization treatment, $\mathrm{kg} / 100 \mathrm{Kg}$ steel, numerically equal with the mass content variation of sulphur in steel, due to the desulphurization; $\mathrm{M}_{S}$ - the atomic mass of sulphur; $\mathrm{M}_{\mathrm{Al}_{2} \mathrm{O}_{3}}, \mathrm{M}_{\mathrm{CaO}}, \mathrm{M}_{\mathrm{CaS}}-$ molar mass of $\mathrm{Al}_{2} \mathrm{O}_{3}$ and respective, of $\mathrm{CaO}$ and $\mathrm{CaS} ; q_{\mathrm{Al} \text {.cons }}$ - the amount of soluble aluminium consumed in the reaction No. 7 given in the table I.

The effects of these modifications of chemical compositions are important as consequences on the thermodynamic equilibrium in the system steel-slag, which evolves towards worse conditions of desulphurization, if they are not corrected, mainly due to the decreasing of the activity of $\mathrm{CaO}$, the increasing of the activity of $\mathrm{Al}_{2} \mathrm{O}_{3}$ and the decreasing of aluminium activity, due to consumption by the transferred oxygen from steel into slag, in the exchange reaction with sulphur. The decreasing of the $\mathrm{CaO}$ content of slag by the above mentioned action is compensated, partially and in a random manner, by the new amounts of $\mathrm{CaO}$ brought by the dolomite lining of ladle, when a such refractory material is used. The main contribution of the consumed dolomite lining to the chemical composition of the slag is brought during tapping, when the kinetic energy of the falling stream of steel has very high values and is dissipated as strong and chaotic movements of the steel in the ladle. It can be considered that the most important part of these amounts of eroded lining are assimilated in slag in about 3 minutes after end of steel tapping. These modifications of chemical compositions lead to modifications of optical basicity of the slag $(\wedge)$, sulphur capacity $\left(\mathrm{C}_{S}\right)$ and activity of oxygen in the steel. An aspect not enough clarified is the specific contributions of $\mathrm{CaS}$ to the optical basicity of the slag. Despite of the fact that there are evaluations showing that $\mathrm{CaS}$ would have a higher optical basicity than $\mathrm{CaO}\left(\wedge_{\mathrm{CaS}}=1.3 ; \wedge_{\mathrm{CaO}}=1.0^{[11]}\right)$, there are not evidences of a whatever small tendency of increasing of any expected favorable effect, due to the presence of $\mathrm{CaS}$ in slag taken into account as a basic component. In an evaluation based on computation, the desulphurization under slag contributes about $17-25 \%$ in the total content of reoxidized aluminium in the range of the soluble aluminium contents of the analyzed heats. In order to show this influence the following situation will be analyzed. The initial chemical composition of the desulphurization slag is $\mathrm{CaO}=52 \% ; \mathrm{MgO}=6 \%$; $\mathrm{Al}_{2} \mathrm{O}_{3}=36 \% ; \mathrm{SiO}_{2}=6 \%$ and the liquid steel to be treated contains initially $0.015 \% \mathrm{~S}$ and a content of soluble aluminium $\mathrm{Al}_{\text {sol }}=0.0417 \%$. The other components of the liquid steel submitted to the desulphurization treatment correspond to the low carbon HSLA steel so the activity coefficient of aluminium in steel can be considered closed to unity. Considering these data at $1,873 \mathrm{~K}$, the initial values of parameters, interesting in desulphurization, are obtained by computation using the adequate relations obtained in this paper and they are presented in the table V. An amount of about of $300 \mathrm{~kg}$ slag, entrapped from converter in ladle during tapping of the steel, the advance of the slag deoxidization up to contents lower than $(\mathrm{FeO}+\mathrm{MnO})<0.5-1.0 \%$ which consumes aluminium in steel and the oxygen from the air entrained by the steel stream, contribute to the increasing of the deleterious effects on the parameters of the desulphurization process. In the table $\mathrm{V}$ a situation close to real situations is presented, showing how the parameters of the desulphurization, mainly those of slags, decrease from their initial 
THE EFFICIENCY AT INDUSTRIAL SCALE OF A THERMODYNAMIC MODEL FOR DESULPHURIZATION OF ALUMINIUM KILLED STEELS USING SLAGS IN THE SYSTEM CAO-MGO-AL $\mathrm{O}_{3}-\mathrm{SIO}_{2}$ LA EFICIENCIA A ESCALA INDUSTRIAL DE UN MODELO TERMODINÁMICO PARA ELIMINAR EL AZUFRE EN LOS ACEROS CALMADOS CON ALUMINIO UTILIZANDO ESCORIAS DEL SISTEMA CAO-MGO-AL $\mathrm{O}_{3}$-SIO ${ }_{2}$

Table V. Comparison between initial estimated and final values of some parameters regarding the desulphurization of steel with slag, starting from an initial content of sulphur in steel $[\mathrm{S}]=0.015$ mass $\%$

Tabla V. Comparación entre los valores iniciales y finales de algunas variables termodinámicas para la desulfuración de acero con escorias captadoras partiendo de fundidos con un contenido inicial de azufre $[S]=0,015 \%$

\begin{tabular}{lll}
\hline \multicolumn{1}{c}{ Parameter $/$ stage } & \multicolumn{1}{c}{ Initial } & \multicolumn{1}{c}{ final } \\
\hline Chemical composition of slag, $\%$ & $\mathrm{C}=55.08 ; \mathrm{M}=6.15 ; \mathrm{A}=32.62 ; \mathrm{S}=6.15$ & $\mathrm{C}=52 ; \mathrm{M}=6 ; \mathrm{A}=36 ; \mathrm{S}=6$ \\
Optical basicity, $\wedge$ & 0.7712 & 0.7589 \\
Sulphide capacity $\mathrm{C}_{\mathrm{S}}, \%$ & $4.6705 \cdot 10^{-3}$ & $3.449 \cdot 10^{-3}$ \\
Soluble aluminium content, \% & 0.0417 & 0.035 \\
Sulphur content in steel, \% & 0.015 & 0.00297 \\
Sulphur partition ratio & 815 & 444 \\
\hline
\end{tabular}

favorable values to final lower and less favorable values. The slag composition in the initial stage is at around 3 min after the end of tapping. It results from data in table $V$ that because of the modifications of the slag composition and of the level of aluminium activity, considered only due to the reoxidization, as consequence of desulphurization, the system steelslag loses an important part of its capacity of desulphurization of the treated steel. Therefore in steel treatments with desulphurization slags an important attention must be paid to the prevention of steel reoxidation and to the keeping at adequate levels the soluble aluminium content, by adequate additions as nature, amount and moment, in order to avoid the prolonging of the treatment times. An accurate evaluation of the changes of the slag chemical composition during desulphurization under slags helps in a major manner in establishing the starting conditions of the desulphurization slag formation, in accord with the different sources of slag and their introduction at adequate moments, during treatment.

\section{CONCLUSIONS}

Based on the own established relations regarding the sulphur capacity $\left(\mathrm{C}_{\mathrm{S}}\right)$ expressed as a function of the optical basicity of the $\mathrm{CaO}-\mathrm{MgO}-\mathrm{Al}_{2} \mathrm{O}_{3}-\mathrm{SiO}_{2}$ desulphurization slag, the activity of $\mathrm{CaO}, \mathrm{Al}_{2} \mathrm{O}_{3}$ and $\mathrm{SiO}_{2}$ in slag, a thermodynamic model to predict the equilibrium parameters of the desulphurization process was established. The model permits to establish the activity of sulphur in equilibrium with $\mathrm{CaO}-\mathrm{MgO}$ $\mathrm{Al}_{2} \mathrm{O}_{3}-\mathrm{SiO}_{2}$ slags of composition in the field of industrial interest and at a known final activity of aluminium in steel, the value of the theoretical final value of the partition ratio of sulphur between steel and slag $\mathrm{L}_{\mathrm{S}}$, and of the theoretical, minimal amount of the slag necessary in equilibrium conditions. The data obtained based on this model are compared with experimental results obtained at industrial scale, by treating heats of 180 tons of LCAK steels, grades of HSLA. A correct evaluation of the different sources of slag, during treatment of steel from the beginning of the taping up to the final moment of treatment is of an outmost importance in the obtaining and keeping an adequate composition of the treatment slag. A major attention must be paid to the desulphurization process itself, which contribute to the lowering of the sulphide capacity of the steel and to the increasing of the oxygen activity in steel by the alumina brought into slag due to the inherent reoxidization by the exchange reaction of sulphur from steel with the oxygen from slag. In absence of correction, this leads to worse final results in desulphurization, compared with the presumed values. On this basis, by adequate evaluated corrections of slag composition and of the quantity of slag, the results at industrial scale in obtaining sulphur contents below the limit of $30 \mathrm{ppm}$ satisfy the requirements and prove the rectitude of the model and of its practical and theoretical improvements. The model allows its transposition in the form of an applied model at industrial scale for the operation of steel desulphurization.

\section{REFERENCES}

[1] K.W. Lange, Int..Mater. Rev. 33(1988) 53-89.

[2] L. Zhang and G. B. Thomas, ISIJ Int. 43 (2003) 271-291.

[3] L. Zhang and G. B. Thomas, Metall. Mater. Trans.B 37 (2006) 733-761. 
[4] K. Ogawa, Proc. 143th \& $144^{\text {th }}$ Nishiyama Technical Symposium, Tokyo, Osaka, Japan, 1992, ISIJ.

[5] B. Debiesme, I. Poissonnet, P. Choquet and F. Penet, Rev. Metall. Paris 90 (1993) 387-394.

[6] H. Gao, Steelmaking (China) 16(2000) 38-43.

[7] Z. Liu and K. Cai, Iron \& Steel(China) 35(2000) 64-69.
[8] P.S. Nita, Metalurgia (Romania) 43 (1991) 16 21.

[9] D.A.R. Kay and J.Taylor, Trans. Faraday Soc. 56 (1960) 1372-1386.

[10] J.Lee and K.Morita, ISIJ Int., 42 (2002) 568594.

[11] J.A. Duffy, J. Chem. Soc. Faraday Trans. 88 (1992) 2397-2400. 